\title{
God as burden: A theological reflection on art, death and God in the work of Joost Zwagerman
}

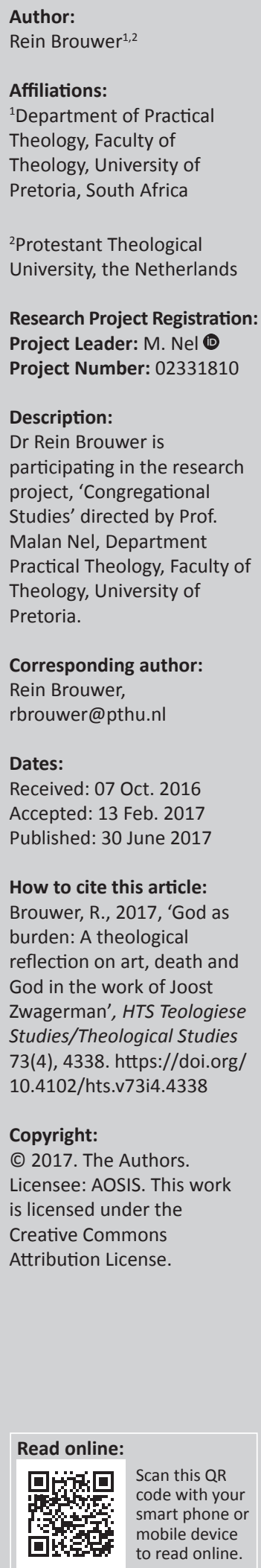

In one of his essays on art, Dutch author and essayist Joost Zwagerman (1963-2015) reflects on the work of (Dutch) South African artist Marlene Dumas (1953). Zwagerman addresses in particular Dumas' My Mother Before She Became My Mother (2010), painted 3 years after her mother died. In his reflections, Zwagerman proposes an interpretation of Dumas' work. He suggests that Dumas, in her art, does not accept the omnipotence of death. Maybe against better judgement, but Dumas keeps creating images that not only illustrate the desire for meaning but also embody this desire. The image and the desire for meaning merge in Dumas' paintings. The painting itself becomes an autonomous 'desire machine', according to Zwagerman. In this article, a (practical) theological reading of Zwagerman's own posthumously published volume of poetry, 'Wakend over God' (2016), is presented, with a specific interest in art, death and God. The sacramental hermeneutics of Richard Kearney and the theopoetics of John Caputo are brought into the conversation to elicit the dimensions of faith and religion in Zwagerman's own 'desire machine'.

\section{Introduction}

In De stilte van het licht [The Silence of the Light], a volume of essays on art and popular culture, published on the day of his death, Dutch author, poet and essayist Joost Zwagerman (1963-2015) reflected on the work of, amongst others, Marlene Dumas (b. 1953). Zwagerman (2015:271-278) addressed in particular Dumas' My Mother Before She Became My Mother (2010), painted 3 years after her mother died. He calls it a 'heartening and uplifting piece of art'. In his reflections, Zwagerman proposes an interpretation of Dumas' work, albeit with necessary caution, because in the end her work can only be interpreted approximately, elusive as it is. He suggests that Dumas does not accept the omnipotence of death, in her art. Maybe against better judgement, Dumas keeps creating images that not only illustrate the desire for meaning but also embody this desire. Dumas' mother seems to have eternal life in the painting. According to Zwagerman, Dumas' work itself is a 'desire machine'. Her art transports the desire for meaning whilst generating desire, even in the face of death.

Zwagerman's incentive to write about Dumas' work came from the first retrospective of her paintings in Europe. In 2014-2015, the Stedelijk Museum in Amsterdam, the Tate Modern in London and the Fondation Beyeler in Riehen, Basel presented an overview of Dumas's work from the early 1970s to 2014, called The Image as Burden (Dumas 2014). The title was borrowed from a painting by Dumas, from 1993, in which a man carries a woman, standing for 'the image', the representational subject of art, that has become a burden. The exhibition intended to draw attention 'to the complexity of the relationship between painting and image, and the potency of the act of painting' (Dumas 2014, 7). Visual representation in media and culture has become a burden because it does not represent reality or truth. At most, it shows one perspective on life, the interpretation of which is filled with ambiguity. Dumas plays with image and (mis)representation, and it is a serious play. She uses pictures and photographs as material to work with, but her paintings change the original to find new meaning. Although there is a connection between painting and original image, Dumas (2014) creates a new world based on an existing image:

The connection that the painting has with reality is different, looser. The portrait (what is presented) and the portrayed (what is represented) occupy the same space, but lead separate lives. A minimum of resemblance is necessary. Not because the painter is copying a photograph (or, as some would say, plagiarising it), but because the painter is questioning the appearance, the visage, the image of the world. Images are ambiguous. No image is ever irrefutable. (p. 141)

So said art historian and critic Dominic van den Boogerd on Dumas' Dead Marilyn from 2008. Images have become suspect. They can mean whatever whoever wants them to mean (Dumas 2014:117). The artist wants us to question the representation in the images the media confronts us 
with by haunting us with the intriguing ambiguity and elusiveness in her own work. In 1993, Dumas wrote about women and painting, responding in a paradoxical way to the annoying question about being a painter and a woman. One of the things she wrote was: 'I paint because I am a religious woman. (I believe in eternity.) Painting doesn't freeze time. It circulates and recycles time like a wheel that turns' (Dumas 2014:70). Painting intends not to freeze images or restrain interpretations. Dumas' painting is about opening the world to complexity and difference, creating meaning as desire.

During his life, Zwagerman not only admired Dumas as an artist but also befriended her. That makes one wonder if we could recognise in his own artistic endeavours the same intention that inspires Dumas' art. Could we read his work also as an autonomous 'desire machine'? Of course, painting is a different form of art than writing novels, essays and poetry and uses a different notion of image. The painter makes images with paint and strokes of a brush, whilst the writer arranges words, which are images in themselves, to imagine a world of meaning. Nevertheless, both artists appeal to the imagination and create a world of imagery. So, does Zwagerman's work embody desire for meaning beyond the mere illustration of this desire, which might even be seen as a definition of art?

This question became quite intriguing after the death of Zwagerman, 08 September 2015. As mentioned, on the day of his death, a volume of essays on art and popular culture was published (Zwagerman 2015). Before his dead, he had written several volumes of essays that were highly appreciated by a general audience. This volume, however, was different, in the way he reflected on God, religion, 'perfect whiteness', absolute silence and emptiness. It seemed like he had some unfinished business with God. His interest in God became even more significant when his final volume of poetry was published, posthumously, with the title 'Wakend over God' ('Watching over God') (Zwagerman 2016). A captivating title that discloses a fascinating wrestling with God in words.

\section{Zwagerman and God}

In this article, I reflect on Zwagerman's 'Watching over God', questioning the nature of the desire for meaning he embodies in his poems. In order to answer this question, I take three steps. Firstly, I refer to the discussion on theological knowledge through 'image' and on the notion of 'iconoclash' (Bruno Latour) in Barnard's, Cilliers' and Wepener's seminal work on worship in the network culture (2014). This discussion underlines the liminality of theological knowledge, which is fundamentally open to multiple interpretations. Furthermore, the authors' approach to (practical) theology, 'starting with contemporary practices of art', 'leading practical theology away from its own discourse to the discourse of art', is paradigmatic for this article. Secondly, I try to ground these practical theological reflections in the 'theological' debate between Richard Kearney and John Caputo on the poetics of the impossible, beyond atheism and theism. Both Caputo and Kearney are looking for the affirmative in the deconstruction of theological positions that got stuck in the dichotomy of theism and atheism. Finding this affirmation will help to evaluate the theological meaning of Zwagerman's poetry about God, even when he is arguing against God. I focus in particular on the 'sacramental hermeneutics' of Kearney to find a tool to discern the nature of desire embodied in Zwagerman's posthumous work. Thirdly, I read and interpret Zwagerman's final publication with regard to what he writes about God. So, my reading and interpretation will be informed by the radical theologies of Caputo and Kearney. Kearney also helps to understand the theological meaning of artistic 'desire'. Referring to Ricoeur's use of 'metaphor' to describe the divine-human exchange, Kearney (2011) asserts that the divine potency expresses itself as a desire, which is an eschatological surplus:

Desire beyond desire. Anatheist desire as a love that answers desire with more desire - and death with more life. And in such a process of mutual traversal, desire surely reveals 'God' as another name for the 'more', the 'surplus', the 'surprise' that humans seek. (p. 80)

\section{Iconoclash}

In their book on liturgical ritual, Barnard and his South African colleagues Cilliers and Wepener introduce several heuristic notions from a humanities discourse to study liturgy, 'image' being one of these (Barnard et al. 2014:169206). They see 'image' as a code to file and communicate information about religion. As a code, it is ambivalent in nature, and it leaves space for different, even contrary interpretations. The code reflects reality and truth, but is also a human construction. The authors connect this phenomenon to the word 'dilemma' and the notion of liminality. They intentionally keep this dilemma open to foreclose too easy one-dimensional interpretations. Moreover, they see it as 'practical theology's modest contribution to world peace and human flourishing' to leave this dilemma undecided (Barnard et al. 2014:171). Information about religion is always ambivalent. Here, the authors are reminded of the prohibition of constructing images in the Decalogue. Knowing God, or anything that exists, and communicating about them are (im) possible. That is how they decode this biblical taboo.

'Image' as a code manifests itself in different shapes: iconic, verbal, discursive, visual, graphic, physical and musical. That is why they can perceive practices of faith as composed and complex codes, composed of different sub-codes, made by men and revealed as divine. From a different perspective, artistic codes, like a painting by Marlene Dumas, or a poem by Joost Zwagerman, also communicate religious information and might contribute to faith knowledge. That is the implication of the reflections on 'image' by Barnard, Cilliers and Wepener.

Their understanding of 'image' is based on the work of Bruno Latour who states that religion, art and science all express themselves in codes as 'images' 'that preserve their double character of being either human constructions or reflections of (objective) truth' (Barnard et al. 2014:174). They also 
borrow the notion of 'iconoclash' from Latour (2002), who describes it as an 'image' that seems to be iconoclastic, but:

when one does not know, one hesitates, one is troubled by an action for which there is no way to know, without further enquiry, whether it is destructive or constructive. (p. 16)

Latour wants to keep the ambivalence of images and translates the decalogical injunction as 'Thou shall not freezeframe any graven image!' (Latour 2002:38). Latour (2002) helps us to ask the right question when reflecting on the theological meaning of art by defining iconoclash as:

what happens when there is uncertainty about the exact role of the hand at work in the production of a mediator. Is it a hand with a hammer ready to expose, to denounce, to debunk, to show up, to disappoint, to disenchant, to dispel one's illusions, to let the air out? Or is it, on the contrary, a cautious and careful hand, palm turned as if to catch, to elicit, to educe, to welcome, to generate, to entertain, to maintain, to collect truth and sanctity? (p. 20)

Is Zwagerman approaching God with a hammer or with a careful hand?

In order to do justice to the specific contexts in which images or codes are invented, Barnard et al. (2014) use the notion of 'translatability':

The notion of iconoclash emphasizes the ambivalence of the divine and human, the notion of translatability emphasizes the ability to invent codes in which the divine and human are contained in any context. (p. 192)

With regard to my subject of interest, it raises the question if the genre of poetry adds something to the understanding of the theological iconoclash in Zwagerman's work.

\section{Poetics of the (im)possible}

The 'radical theologies' of Richard Kearney and John Caputo throw an interesting light on how the practical theologians, Barnard, Cilliers and Wepener, apprehend the notion of iconoclash and the fundamental ambivalence and ambiguity of images. Both of these philosopher-theologians are involved in hermeneutics. Caputo, inspired by Derrida, developed a deconstructive, radical hermeneutics, and Kearney developed a dialectical hermeneutics inspired by Ricoeur. Another way of phrasing this difference is that Kearney's focus is on a poetic (or hermeneutic) of the possible, and Caputo's focus is on a poetic of the impossible. Their agreement and disparity lead to interesting debates (Dooley 2003:107-127; Kearney \& Zimmerman 2016:193-218) and justify employing the 'theological' proficiency of both of them.

Using 'poetics', Caputo wants to impede the closure of the event that is harboured in the name of God. Names, or codes, or images are always prone to lock up the dynamics of the eschatological event, to 'ontologise' what haunts us. Poetics 'is an evocative discourse that articulates the event' (Caputo 2006:103), which becomes a theopoetics when it takes up the name of God. It traces the contradiction and interdiction and remembers the paradoxical character of what is always coming, which Caputo with Derrida calls the 'impossible'. Theology is the hermeneutics of the impossible event, 'something unforeseeable that shatters our horizon of expectation, which is quite exciting' (Caputo 2006:103). For Caputo, God insists, and we exist. God is a call that is visited upon us, which demands our response. And this call, this coming event, is characterised by undecidability, by 'perhaps', which requires the risk of faith. 'Because it seeks access to the inaccessible, to the unprogrammable, to the uncertain, to the "event", "perhaps" affirms a more obscure and radical faith' (Caputo 2013:6). Talking about God implies a grammatology of the 'perhaps', which suits a weak theology and fits a theopoetics.

In a world estranged from God, Kearney tries to safeguard speaking about the sacred and God by finding a free space that precedes the dichotomy between theism and atheism: anatheism (Kearney 2011). In the concept of 'anatheism', Kearney elaborates on his previous reflections on God as 'possest' (Nicholas von Cusa), the 'God who may be', God as an eschatological promise (Kearney 2001). Anatheism is the space of the possibility of God after God and is closely connected to hospitality to the stranger. Kearney, like Caputo, following Derrida ('hostipitality'), underlines that the guest that we welcome always could turn out to be an enemy. Nevertheless, welcoming the S/stranger (Christ as the 'hospes' from Matthew 25) is the primal act of faith, 'anatheistic wagering'.

Both Kearney and Caputo acknowledge a plurality of interpretations with regard to the absolute. 'There are multiple religious traditions, each of which is true in its own way, and with a truth that does not subtract from the truth of others', according to Caputo, and 'anatheism never ends', according to Kearney (Kearney \& Zimmerman 2016:201202). Consequently, they relativise the different (non-) religious positions. Caputo states the difference between the presentable positions and an unpresentable 'affirmation'. It might be confusing that Caputo, with Derrida, also talks about 'undecidability', but he accentuates that undecidability is the condition of possibility of deciding. Undecidability implies making a decision, and this decision is rooted in an underlying affirmation, a common ground on which we stand. Caputo refers here to Kearney's hospitality and to Derrida being concerned with questions of justice, hospitality, forgiveness and the gift, as examples of such deeper affirmations (Kearney \& Zimmerman 2016:213-217).

\section{Sacramental hermeneutics}

So, Kearney would read Zwagerman's poems as artistic hospitality to the S/stranger, friend or foe, or maybe even friend and foe. And Caputo would look for the affirmation underneath Zwagerman's writings and maybe even recognise the weakness of the event that is harboured in the name of God. Both present us with ample reason for a theological reflection on the work of a writer who 'rightly 
passed for an atheist'. Undertaking such a reflection requires an adequate tool, which Kearney provides us with.

Kearney distinguishes three narrative sources for the anatheistic hospitality to the stranger: sacred experiences revealed to us by religious traditions; ordinary, existential experiences; and 'poetics', another word for literature and art. Connecting to the last source, Kearney acknowledges 'sacred narratives of gift and grace' in poetics, and he mentions the testimony of artists and poets that something is realising itself through them. Kearney speaks freely of 'sacramental' and 'carnal hermeneutics'. There is 'transcendence in immanence'. 'God is everywhere and in all things'. 'The divine is potentially incarnate in all things' (Kearney and Zimmerman 2016:50). Maybe not that strange for a Roman Catholic, but Kearney has a deeply sacramental view of life, honouring God embodied in the material. In his Anatheism, he discusses literature by James Joyce, Marcel Proust and Virginia Woolf as examples of authors who illustrate the anatheistic paradigm. In their work, he discloses a sense of transcendence, a 'eucharistic imagination', art as religion, which exemplifies a return to the sacred. Kearney witnesses in these authors 'the consecration of ordinary moments', 'acts of transfiguration', 'epiphanies', which makes it possible to discern a grammar of transubstantiation in these narratives of sacramental sense (Kearney 2011:102-103). He presents them as examples of 'sacramental aesthetics' (Kearney 2011:118). Reading their work, Kearney identifies three hermeneutic modalities or modes of transubstantiation (intra-, inter- and trans-textual): (1) the transfusion of one character into another or one moment into another; (2) the transmuting of one narrative into another or the transliteration of eucharistic liturgy into sacramental re-enactment; (3) the conversion of the author into the narrator or the fictional characters, and the conversion of the textual creation into the reader (Kearney 2011:127-128). This sacramental paradigm of transubstantiation is very much influenced by Ricoeur's stages of interpretation: prefiguration, configuration and refiguration. Kearney phrases this as the movement from flesh becoming word in the text and word becoming flesh in the reader. It is a matter of choice, he writes, but it is possible to retrieve the sacred in the secular, 'to celebrate the bread and wine of quotidian existence as eucharistic epiphanies' (Kearney 2011:129).

Let me recap the ground I covered so far. Kearney's sacramental hermeneutics presents us with a tool to read literature from a paradigm of transubstantiation, being attentive to epiphanic transfigurations within a text, between the text and other texts, and in the possible appropriation of the text by the reader. This poetic hermeneutics follows from the radical theological intent to welcome the S/stranger and being attentive to the 'affirmation' beyond, before or beneath any theistic, atheistic or agnostic stance to life. The openness to the unexpected in art and religion, which is always a risk, a wager, because we are never sure who knocks at the door, resonates with the fundamental ambiguity of 'images', and the possibility of multiple, sometimes 'clashing' interpretations of an icon, which always needs to be interpreted from its context.
Based on this, I will take Zwagerman's referring to God as a serious contribution to retrieving the sacred from the secular. 'Watching over God' can be read as material for theological reflection, with the potential to discern affirmative, epiphanic moments where desire is embodied in his poems.

\section{'Watching over God'}

'I have written the volume, literally, in a state of feverish daze, within a period of two months' (Kellerhuis 2015). This is what Zwagerman himself said about 'Watching over God', the outcome of 'a brilliant idea'. The volume with 44 poems was published 3 months after his death. 'It is a complaint against God, and desire for God, at the same time', according to his publisher. The back cover of the book calls it a battle of faith with the Supreme Being, literally and imaginary. 'The volume sings in different keys about the struggle with the Angel' (Zwagerman 2016).

Critics mostly amplified the gloomy and dark character of the poems. One critic wrote: 'these are psalms and lamentations of a desperate believer looking for existential meaning in a dark world'. This critic also commented that Zwagerman was deemed to be a secular writer, from whom nobody expected religious poetry. Still, his notion of God has nothing to do with Christian faith or the God of the Bible. 'It is the tantalizing presence of a power who remains invisible' (Schouten 2016). Another critic calls the volume 'a theological project', but notices the absolute emptiness and hopelessness that breaks through in several places (Middag 2016). Theologian Van den Brom (2016) declared:

Reading these poems I felt like a voyeur in the most inner private life of a desperate man who screamed to God for a connection, a relation, but finds himself ignored by an indifferent God who is not interested in Zwagerman. (p. 188)

He compares Zwagerman with Hiob, abandoned, lost, screaming for God.

But what about affirmation, desire, and welcoming the stranger? Let me present a few poems to listen to the poet himself. The translations are mine:

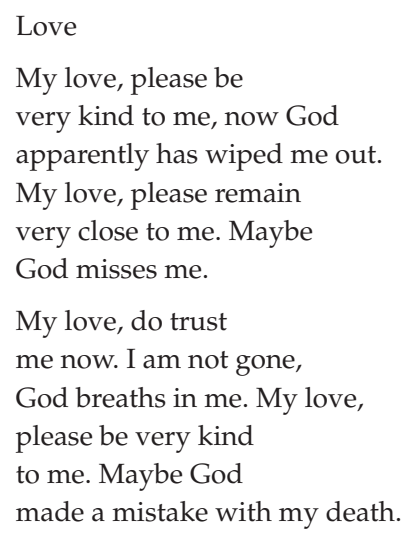

This is the one but last poem in the volume. What strikes me is that God is an agent, acting in a very personal manner towards the I. At first, God seems to act in a destructive way, 
but the I, nevertheless, still expects a turn of events, speculating on a mistake of the One who breathes in him. Moreover, this assumption is the ground for the kindness and trust of his loved one.

Several poems indeed articulate a sense of being lost and abandoned. But interestingly this sense of being left behind connects with the notion of waiting for the creative process. As if the absence of inspiration to write is related to the experience of being forgotten by God:

Master

The master raises a question in the classroom.

You are not in the classroom.

You have to wait, in the hall.

'When is something art?'

De kids write their answer down.

Tom/Kick: When it is beautiful.

Max: When it is summer.

Bodhi: When it is a bit cool.

Ebba: When you are in the museum.

Jules: When it gives light.

Selma: When you've done your best.

Quirijn/Kesso: When something shines.

Your answer does not count.

'When God gives his blessing.'

Always you stand waiting,

and always it is waiting

for a longer waiting.

The master leaves you behind in the hall.

You are still standing there, for so long now.

It could be a real childhood memory, or a bad dream about being singled out at school and feeling lost. But maybe it is the image of the poet waiting for inspiration, waiting for something to come:

Now I wait, helpless, for one place in

this poem where God lets me stay.

I wait till He says something in these lines.

(From 'Bottom')

There are several poems which do refer to his childhood, but they also read like 'older residue', the material (feelings, fears and experiences) that dreams or nightmares are made off to haunt us in the present. Maybe God is also a haunting older residue for Zwagerman. He was done with God a long time ago. In a poem titled 'Done', he writes: 'At an early stage I had had it with God', and 'God really needed to get wiped out of my life'. In one of the poems that I find difficult to understand ('System'), he seems to combine the experience of a not very helpful meeting with a minister, with the metaphor of committing suicide, and getting rid of God. But the volume in itself makes it quite clear that God keeps haunting him. In the poem 'Nothing', he refers to a 'spoilsport' and a 'killjoy', in who one could recognise God without the poet naming God. God spoils the joy by calling the I back from Nothingness, absence and emptiness. but in the end $\mathrm{He}$ is also impotent. He watches the $\mathrm{I}$, who travels into Nothingness together with Meister Eckhart, 'in silent departure yet sink/in completely unfrozen ice'. In another poem, titled 'Ground', God is called a killer, who is out there to kill the I. There is also darkness, and the darkness is a mean dog. The I gets killed, but lives on. The mean dog dies also. He whines. God whines. The author becomes the dog. 'Whining we are one./God, the dog, me, we are/together, we are deprived of all ground'.

These images are rather unnerving and frightful, ominous and threatening. In the poem 'Kosmos' he writes: 'Nowhere a promise, nothing reaches out'. And 'I am enclosed by the vastness of a boarded grave'. The poem ends with: 'A black meteor comes/towards the clear cosmos'. It might be explained by the personal situation of the author. In an interview published the day after his dead (Kellerhuis 2015), Zwagerman talked about suffering from Bechterev disease, a chronic inflammatory autoimmune disease that affected his life strongly. On top of that he was struck by a severe depression. 'Watching over God' was written in a short period of time, when the author was coming out of this depression. More than one poem seems to reflect the experiences and the suffering of the author during his mental illness. In a poem called 'Holy', he describes with a gruesome metaphor (getting raised in a body bag like a flag, which then becomes a canopy) the feelings which might be connected to his depression. The final verse of the poem goes like this:

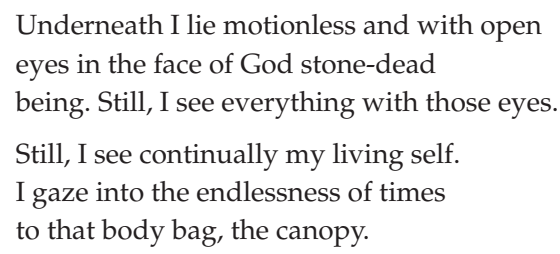

One can imagine that in such circumstances waiting for release, redemption, salvation becomes a major theme. One, quite long poem is titled 'Savior'. Without mentioning Jesus, there are several references in the poem to Jesus. The poem can be read as a prayer, a lamentation or a sermon to the saviour to save. The I imagines how it will be when the saviour saves, and everyone is saved, including the I: 'You save me from myself, my petty worries/all my mental spasms'. In the poem 'Sleep', the I's body waits for someone, who must be God, to pick up his discarded soul. The volume opens with a telling poem using the metaphor of a phone call, voicemail and number recognition. The I receives phone calls, but when he picks up he only hears a breath, far away. When the display shows the number ('of a country I don't know'), he calls back and gets the voicemail: 'Hello, this is God, I am not here'. The I finally leaves a message after the beep once he has got a secret number. 'That day is now, there is connection. I dial/the number. No answer. He beat me/ He installed my number'. The poet is called by God, haunted by God. His reaction shows anxiousness and desire, but once he finds the courage to contact God there is no answer. Not because God is not there, but because the I is abandoned by God.

There is a poem titled 'Abandoned', which seems to reflect the position of a popular author (Zwagerman?), and how this 
being part of the 'masses' affects his relationship with his children. There is happiness, blessing, even election, in this popularity, but 'why is it then unlivable here?' It ends like this: 'And think what I have never in a poem, let/alone outside it expressed in plain:/it is so god almighty lonely here'. But who is alone? The poet, yes, and God also:

\section{Death}

God, Who is lonely,

despises Himself,

on impulse commits suicide,

because He fears His forthcoming

creation.

God, in one go dead by His own hand.

That must have been the big bang.

In this poem, God, death, and creation come together. In one respect, the poem suggests that God is dead and gone, and what is left is life, existence as we know it. But it is also possible to read this poem as an expression of how creative art is coming from some divine inspiration. Maybe through death, but towards resurrection in the artist and poet. It could be the reason for the poet's confession (maybe better 'circumfession' with Derrida; see Caputo 1997:281-308) of faith:

\section{Existence}

Nevertheless, I confess

that I, against all odds,

finally belief in Him.

His greatest and final achievement:

He is not there.

He is all-embracing

absence.

I don't mind.

I am there neither.

It creates a bond.

In His accomplished vacuum

He remains, of course,

out of principle blind and deaf.

That is sad:

people long for Him.

Still He is here.

Daily, He raises in me.

People don't see it.

I can't help it.

It is Gods dirty trick in a nutshell.

God is present in the artist; God is present in the creative force of art. God is replaced by art. That is what is articulated in the poem 'Art', where he writes 'Bendable and piously I have/arched a god in art'. Notice the lowercase letter in 'god', whilst everywhere else he uses a capital letter for God, whom he has rejected, and on whom he already for a long time has not placed his bet, as he writes in the same poem. In another poem ('White'), the I got punished by God for believing and trusting in art. 'God had me put away in his creation', and 'God had me like a candle flame/extinguished between index finger and thumb'.
In several poems, the poet seems to take the place of God as artist and creator. In 'Clean', the I is wax and a cloth which clean for God: 'again I repeat the noise and echo of creation'. In 'Dream', the I 'lents his voice to God'. 'Duty' begins with 'There are those days/that God, sad and weary, / no longer beliefs in me'. 'Here' claims: 'Creation has for a long time now by/God been abandoned, exists/no longer, except here'. And 'here' is the poem itself. Another example is 'Grace'. In this poem, the I becomes a big red pimple on the face of God. 'As pimple I grow into His creation'. But the pimple gets squeezed. 'I die in Him by squirting out of Him'. The image is not very tasty, or tasteful, but it is quite adequate in communicating the pain and the release of the creative process and maybe also the divine inspiration, 'grace'. There are a few poems that might hint at a writer's block, maybe related to Zwagerman's depression. And it might be telling that in some of the poems Zwagerman uses sexual language (masturbation, penetration and orgasm). It indicates the poet is waiting for something to come, to end his (artistic) impotence, and why he is anxious about getting released. But also, when this grace comes, it comes through the darkness or accompanied by darkness. Being an artist, being the voice of God, is hard work. In the end, there is light, like the title of the final poem. But the last word of the volume is sadness:

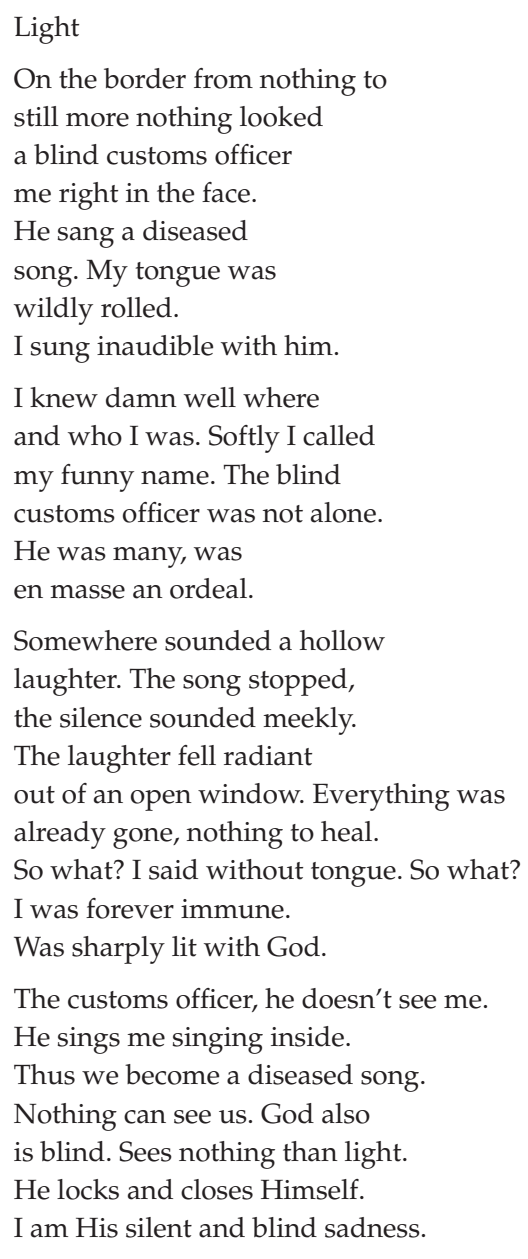

The poem reads like a nightmare. The I crosses a border, from nothing to nothing, where everything is gone, and nothing to heal. Still, the I is lit by God, immune to what could have struck him. It could imply that the poet has come to accept 
his physical and mental situation, probably with sadness, but still. God is locked up in himself, and the poet is left behind to exist God's insistence.

\section{Conclusion}

With the last reference to Caputo, I suggest that Zwagerman as a poet waits for the event to come and welcomes the stranger (God), even when he appears to be a burden. When we ponder his language, it does not seem to be a 'weak' event. On the contrary, it comes like a killer, threatening, stalking. But on the other hand, there is also the event as a creative force the poet is waiting for, longing for, to release him and save him from impotency and death. Zwagerman's posthumous poems, which according to artist Marc Mulders, express a religious coming out (De Lange 2015), embody an ambivalent 'image' of God. The 'image' of his poetry definitely represents a case of iconoclash. There is something to be said for the opinion that Zwagerman approaches God with a hammer. Or is it a careful hand in the disguise of a hammering fist? What to think of these last lines from a twoverse poem titled 'Ten', referring to the Ten Commandments?

Poetry: the never sufficient gesture.

Gods senses which I stroke impotently.

Only when my ashes are scattered

will God feel my deepest inside.

The poet compares his work to the Ten Commandments, written in stone, and then engraved in the hand of God. Poetry is stroking, caressing God's sense. It is a lovely image, reminding one of a cellist playing her instrument, a painter brushing her canvas and a mistress touching her lover's body. But it seems to be in vain, because there is an inner world from which the desire comes that can only to be seen after death. These lines move me, because they try to touch what cannot be grasped, that is the secret of our deepest feelings. But still, the poet creates these lines. So, it can be touched. In writing poetry, and in making art, the creator is not impotent, even though he or she creates impotence in words or on canvas. In that sense, Zwagerman's poetry represents some sort of 'affirmation' of the 'impossible', perhaps.

Or course, there is no final verdict. I leave the dilemma open to foreclose too easy one-dimensional interpretations. The anatheistic wager, beyond theism and atheism, helps to retrieve the sacred in the secular, and even to leave space for the possibility of God after God. Maybe Zwagerman's 'watching over God' is more a poetics of the impossible (Caputo) than the possible (Kearney); nevertheless, his final volume of poetry provides us with epiphanic moments where desire for a divine surplus, a sacred surprise, is embodied. It ends with 'Light'. Watching over God, waiting for his blessing.

\section{Acknowledgements Competing interests}

The author declares that he has no financial or personal relationships which may have inappropriately influenced him in writing this article.

\section{References}

Barnard, M., Cilliers, J. \& Wepener, C., 2014, Worship in the network culture. Liturgical ritual studies. Fields, methods, concepts and metaphors, Peters, Leuven.

Caputo, J., 1997, The prayers and tears of Jacques Derrida. Religion without religion, Indiana University Press, Bloomington, IN.

Caputo, J., 2006, The weakness of God. A theology of the event, Indiana University Press, Bloomington, IN.

Caputo, J., 2013, The insistence of God. A theology of perhaps, Indiana University Press, Bloomington, IN.

De Lange, H., 2015, 'Hallo met God, ik ben er niet' (Hello, this is God, I am not here), Trouw, 28 November, viewed 04 July 2016, from http://www.trouw.nl/tr/ nl/4492/Nederland/article/detail/4197210/2015/11/28/Hallo-met-God-ik-bener-niet.dhtml

Dooley, M. (ed.), 2003, A passion for the impossible. John D. Caputo in focus, State University of New York Press, Albany, NY.

Dumas, M., 2014, 'The image as burden', in L. Coelewij, H. Sainsbury \& T. Vischer (eds.), Tate Publishing, London.

Kearney, R., 2001, The god who may be, a hermeneutics of religion, Indiana University Press, Bloomington, IN.

Kearney, R., 2011, Anatheism. Returning to God after God, Columbia University Press, New York.

Kearney, R. \& Zimmermann, J. (ed.), 2016, Reimagining the sacred. Richard Kearney debates God, Columbia University Press, New York.

Kellerhuis, T., 2015, 'Laatste interview Joost Zwagerman: "Zelfmoord beschouw ik als no-go-area"' (Last interview Joost Zwagerman: I consider suicide is a no-go-area) HP/De Tijd, 9 September, viewed 30 June 2016, from http://www.hpdetijd. $\mathrm{nl} / 2015-09-09 /$ laatste-interview-joost-zwagerman-zelfmoord-beschouw-ik-alsno-go-area/

Latour, B., 2002, 'What Is Iconoclash? Or is there a world beyond the image wars?', in P. Weibel \& B. Latour (eds.), Iconoclash, beyond the image-wars in science, religion and art, pp. 14-37, MIT Press, Cambridge, MA

Middag, G., 2016, 'Waar is nog troost?' (Where do we find comfort?), NRC Handelsblad, 26 January, viewed 30 June 2016, from http://www.nrc.nl/ handelsblad/2016/01/26/waar-is-nog-troost-1583607

Schouten, R., 2016, 'Zwagerman zoekt god, maar vindt hem niet' (Zwagerman looks for God, but he can't find him), Vrij Nederland, 27 January, viewed 30 June 2016, from https://www.vn.nl/joost-zwagermans-laatste-gedichten-klaagliederen-vaneen-wanhopige-ongelovige/

Van den Brom, L., 2016, 'De arme Joost Zwagerman in zijn roep tot God', Kroniek, Kerk en Theologie 67/2, April, pp. 187-188.

Zwagerman, J., 2015, De stilte van het licht. Schoonheid en onbehagen in de kunst (The silence of the light. Beauty and discontent in art), Arbeiderspers, Amsterdam.

Zwagerman, J., 2016, Wakend over God. Gedichten (Watching over God. Poetry), Hollands Diep, Amsterdam. 